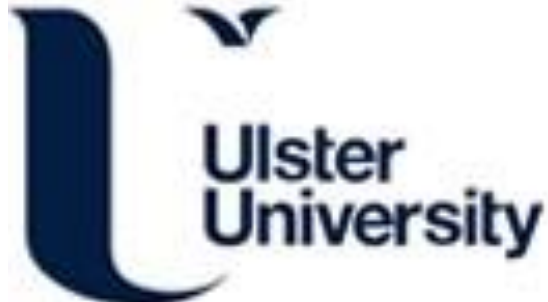

\section{Patterned cell culture substrates created by hot embossing of tissue culture treated polystyrene}

Brown, A., Burke, GA., \& Meenan, BJ. (2013). Patterned cell culture substrates created by hot embossing of tissue culture treated polystyrene. Journal of Materials Science: Materials in Medicine, online.

https://doi.org/10.1007/s10856-013-5011-5

Link to publication record in Ulster University Research Portal

Published in:

Journal of Materials Science: Materials in Medicine

Publication Status:

Published (in print/issue): 01/01/2013

DOI:

10.1007/s10856-013-5011-5

\section{Document Version}

Author Accepted version

\section{General rights}

Copyright for the publications made accessible via Ulster University's Research Portal is retained by the author(s) and / or other copyright owners and it is a condition of accessing these publications that users recognise and abide by the legal requirements associated with these rights.

\section{Take down policy}

The Research Portal is Ulster University's institutional repository that provides access to Ulster's research outputs. Every effort has been made to ensure that content in the Research Portal does not infringe any person's rights, or applicable UK laws. If you discover content in the Research Portal that you believe breaches copyright or violates any law, please contact pure-support@ulster.ac.uk. 


\section{Patterned cell culture substrates created by hot embossing of tissue culture treated polystyrene}

Alan Brown 1,*

Phone +44 2890368814

Fax +44289036 6863

Email a.brown@ulster.ac.uk

George A. Burke 1

Email g.burke@ulster.ac.uk

Brian J. Meenan 1

Email bj.meenan@ulster.ac.uk

${ }^{1}$ University of Ulster, Shore Road, Newtownabbey, BT37 0QB UK

\section{Abstract}

Patterning materials such that they elicit a different cell response in different regions would have significant implications in fields such as implantable biomaterials, in vitro cell culture and tissue engineering and regenerative medicine. Moreover, the ability to pattern polymers using inexpensive, currently available processes, without the need for adding proteins or other biochemical agents could lead to new opportunities in biomaterials research. The research reported here demonstrates that by combining the plasma surface treatments used to create commercial grade tissue culture treated polystyrene, with controlled hot embossing processes, that distinct regions can be created on a substrate that result in spatial control of endothelial cell adhesion and proliferation. As well as the topographical changes that result from hot embossing, significant changes in surface chemistry and wettability have been observed and characterised and the resultant effects on endothelial cell responses evaluated. By spatially controlling endothelial cell adhesion, proliferation and subsequent angiogenesis, the processes outlined here have the potential to be used to create a range of different substrates, with applications in the development 
of assays for high throughput screening, the patterning of implantable biomaterials or the development of smart scaffolds for tissue engineering.

\section{Introduction}

The ability of endothelial cells to form a network of cord and tube structures forms the basis of both research into angiogenesis and the provision of a vascular network for 3-dimensional tissue engineered constructs. Gradients of growth factors [1] and the containment of endothelial cells either within channels [2] or around fibre structures [3] have been used to spatially control the culture of endothelial cells and thus the subsequent processes of angiogenesis. Spatial control of angiogenesis could have applications in the development of new angiogenesis assays, as well as in the development of strategies for vascularisation of tissue engineered constructs.

Endothelial cell responses can also be altered by culturing on topographically and/or chemically modified surfaces. For example, the alignment of endothelial cells to micro- and nano-scale grooves in polydimethylsiloxane (PDMS), coated with a fibronectin monolayer [4], and to nano- and micro-scale grooves in polyurethane substrates, especially those with groove widths greater than $800 \mathrm{~nm}$, but not to arrays of pore structures [5] have been observed. Other studies have shown that alignment is more pronounced for deeper groove depths on PDMS substrates [6, 7] and also with smaller groove widths [7]. The shape of endothelial cells has also been modified by culturing on cell-adhesive and non-adhesive regions that are created on substrates at the micro-scale. The resulting "shape-engineered" endothelial cells are elongated and aligned, and also show alignment of the actin cytoskeleton [8] In addition, cells aligned in this way show a reduction in mRNA expression for vascular cell adhesion molecule-1 (VCAM-1), a result which is similar to that found with endothelial cells aligned by exposure to shear stress [9]. On lines of collagen or fibronectin, endothelial cells and the actin cytoskeleton will align parallel to the lanes [10].

It is clear therefore, that spatial control of where endothelial cells are cultured, as well as control of cell shape can both play a role in the responses of endothelial cells to an engineered surface. Modifications in surface topography and surface chemistry either individually, or in combination, can provide for a means of both spatial control and shape control, and have the potential to elicit specific cell responses, including changes in cell adhesion, 
differentiation and alignment. Significant differences in cell response can be observed for relatively subtle changes in the biomaterial surface on which the cells are cultured, and by using micropatterning techniques it is possible to create adjoining regions where cell responses are different. Many of these patterning methods involve the use of proteins or biochemical factors, with resultant shelf-life and refrigerated storage requirements.

Polystyrene has been used for the culture of adherent cells for many years, as it is easy to process, and is inexpensive. As a result, these surfaces are well understood and are often used as control surfaces in cell studies. Native polystyrene, however is not a suitable surface for adherent cell culture [11, 12] and needs to be pre-treated in order to improve the wettability of the surface and thus improve cell adhesion. These pre-treatments typically both increase the surface roughness and add oxygenated chemical groups to the surface $[13,14]$, producing tissue culture treated polystyrene (TCPS).

This research uses hot embossing to make specifically defined changes to the topography and surface chemistry of TCPS substrates, and by characterising the changes in topography, roughness and surface chemistry, this study shows that spatial control over adhesion, proliferation, alignment and subsequent processes of angiogenesis can be affected by the TCPS surface, and allows for a simple method of producing adhesive and non-adhesive regions on TCPS substrates.

\section{Materials and methods}

\subsection{Hot embossed micro-featured substrates}

Tissue culture treated polystyrene (TCPS) substrates were prepared from commercial grade T-175 tissue culture flasks (Sarstedt, Germany). $100 \mathrm{~mm}$ diameter discs were cut from the cell culture surface of the flasks using a Thermocut hot wire cutter (Proxxon, Germany). Untreated polystyrene (PS) discs were cut from $1.2 \mathrm{~mm}$ thick PS sheets (Goodfellow, UK) as a control.

Samples were hot embossed at $110{ }^{\circ} \mathrm{C}$ and $10 \mathrm{kN}$ embossing force under vacuum ( $<1$ mbar) in an EVG520 HE automated hot-embossing tool (EVGroup, Austria) using silicon stamps, fabricated using photolithography and plasma etch processes at Tyndall National Institute (Cork, Ireland) as part of the National Access Programme. A number of feature arrays were produced by this hot embossing process and these are described in Table $\mathbf{1}$. 


\section{Table 1}

Names and descriptions of micro-features created by hot embossing

\begin{tabular}{|l|l|l|l|l|}
\hline $\begin{array}{l}\text { Pattern } \\
\text { name }\end{array}$ & $\begin{array}{l}\text { Feature } \\
\text { type }\end{array}$ & $\begin{array}{l}\text { Feature } \\
\text { width } \\
\mathbf{( \mu m )}\end{array}$ & $\begin{array}{l}\text { Feature } \\
\text { height } \\
\mathbf{( \mu m )}\end{array}$ & Array details \\
\hline $\begin{array}{l}3.2 \mu \mathrm{m} \\
\text { ridge }\end{array}$ & $\begin{array}{l}\text { Rectangular } \\
\text { ridge }\end{array}$ & 3.2 & 1 & $\begin{array}{l}\text { 10 mm long parallel ridges } \\
\text { with } 3.2 \mu \mathrm{m} \text { spacing }\end{array}$ \\
\hline $\begin{array}{l}3.2 \mu \mathrm{m} \\
\text { pillar }\end{array}$ & $\begin{array}{l}\text { Circular } \\
\text { pillar }\end{array}$ & 3.2 & 1 & $\begin{array}{l}\text { Hexagonal close packed } \\
\text { array with } 4.8 \mu \mathrm{m} \text { centre- } \\
\text { to-centre spacing }\end{array}$ \\
\hline $\begin{array}{l}3.2 \mu \mathrm{m} \\
\text { short } \\
\text { ridge }\end{array}$ & $\begin{array}{l}\text { Rectangular } \\
\text { ridge }\end{array}$ & 3.2 & 1 & $\begin{array}{l}\text { 200 mm long parallel ridge } \\
\text { array with 3.2 } \mu \mathrm{m} \text { spacing } \\
\text { and separated by 200 } \mu \mathrm{m} \\
\text { from the adjacent array }\end{array}$ \\
\hline
\end{tabular}

$3.2 \mu \mathrm{m}$ ridge arrays were chosen based on the ability to fabricate hot embossing stamps using standard contact photolithography and being in the size range that has been shown to result in alignment and elongation of endothelial cells. The pillar arrays have the same proportion of raised and planar areas as the ridges, but do not have the specific orientation of the ridge arrays. The short ridge arrays were investigated to see the effect of patterned and unpatterned regions in close proximity.

\subsection{Surface characterisation}

\subsubsection{Stylus profilometry}

A Dektak 8 Advanced Development Profiler (Veeco, USA) was used to measure feature dimensions produced by the hot embossing process and to measure surface roughness of the polymer surfaces after embossing. The profiler was fitted with a $5 \mu \mathrm{m}$ diameter stylus at a scan force of $3 \mathrm{mg}$. Line scans of $1000 \mu \mathrm{m}$ were performed on samples with this stylus to investigate step heights.

\subsubsection{Static contact angle measurement}

The wettability was measured using a CAM 200 (KSV Instruments, UK) on the various embossed and non-embossed substrates. The static water contact angle was measured using the sessile drop method using a $5 \mu \mathrm{L}$ drop of DI water. 


\subsubsection{Atomic force microscopy (AFM)}

As well as measuring the roughness using stylus profilometry, surface roughness was also measured on a smaller number of samples by atomic force microscopy (AFM) using a Dimension 3100 Atomic Force Microscope (Veeco Instruments Inc., USA) fitted with a TESPA tip (Veeco Instruments Inc., USA) with resonant frequency $246-375 \mathrm{kHz} .10 \mu \mathrm{m} \times 10 \mu \mathrm{m}$ scans were performed at $1 \mathrm{~Hz}$ scanning rate resulting in $512 \times 512$ resolution maps. The Amplitude set point was $1.46 \mathrm{~V}$. After scanning, results were analysed using Nanoscope v6.14R1 software (Veeco Instruments Inc.), where the arithmetic mean roughness $R_{a}$ was calculated for the surface and a 3-D rendering of the surface was produced.

\subsubsection{X-ray photoelectron spectroscopy (XPS)}

X-ray photoelectron spectroscopy (XPS) was used to determine the chemical composition of the PS and TCPS before and after the hot embossing process. The technique was used to quantify the carbon and oxygen concentration at the polymer surface and to therefore evaluate the effect of processing conditions on the oxygen containing functional groups that are present on TCPS after tissue culture treatment.

XPS analysis was performed using a Axis Ultra DLD spectrometer (Kratos Analytical, Japan) using monochromated $\mathrm{Al} \mathrm{K \alpha}$ X-rays operating at $15 \mathrm{kV}$ and $10 \mathrm{~mA}$. The operating pressure was lower than $6 \times 10^{-6} \mathrm{~Pa}$. A hybrid lens mode was used during analysis. Charge neutralisation was achieved using an immersion lens with a filament current of between 1.9 and $2.1 \mathrm{~mA}$ at a charge balance voltage of between 3.2 and 3.6 V. Three spots were analysed per sample and wide energy survey scans (0-1300 eV binding energy) as well as high resolution spectra for C 1s $(278-295 \mathrm{eV})$ and $\mathrm{O} 1 \mathrm{~s}(525-540 \mathrm{eV})$. Pass-energy was $160 \mathrm{eV}$ for the wide energy survey scans and and $20 \mathrm{eV}$ for the high resolution spectra.

Quantification of the atomic \% oxygen at the surface from the high resolution spectra was conducted by subtracting a linear background and calculating the area under the peaks on the $\mathrm{C} 1 \mathrm{~s}$ and $\mathrm{O} 1 \mathrm{~s}$ spectra using Vision 2.2.8 software (Kratos Analytical, Japan). At least two samples of each type were analysed.

\subsection{Cell culture}

$10 \mathrm{~mm}$ square coupons were used for cell culture tests. Bovine Aortic 
Endothelial Cells (BAEC) were seeded onto pristine and hot embossed TCPS coupons at $5 \times 10^{4}$ cells $/ \mathrm{cm}^{2}$ and cultured in Minimum Essential Media, with the addition of $10 \%$ Foetal Bovine Serum and antibiotic and antimicotic supplements at $37{ }^{\circ} \mathrm{C}$ and $5 \% \mathrm{CO}_{2}$ in a cell culture incubator. Primary cells between passage 4 and 8 were used in the cell culture experiments described here. Cell numbers, aspect ratio and alignment were assessed after 48 and $72 \mathrm{~h}$ and the longer term effects were assessed after a further 7-10 days in culture.

\subsubsection{Fluorescent and immunofluorescent labelling}

In order to visualise morphological and cytoskeletal changes in response to the micro-features, samples were stained using both fluorescent and immunocytochemical labelling procedures. Cell monolayers were fixed in a solution of $4 \%$ paraformaldehyde containing $0.1 \%$ Triton X-100 if the plasma membrane was to be permeabilised. As required, either the plasma membrane was labelled using Alexa-Fluor 546 conjugated Wheatgerm Agglutinin or the actin cytoskeleton was labelled using Alexa-Fluor 488 conjugated Phalloidin. For immunocytochemical labelling, samples were incubated in a primary antibody, targeted against $\beta$-tubulin, for $1 \mathrm{~h}$ at $37^{\circ} \mathrm{C}$, followed by incubation with a fluorescent secondary antibody conjugated with Alexa Fluor 594, targeted against the primary antibody, for $45 \mathrm{~min}$ at $37^{\circ} \mathrm{C}$. Cell nuclei were labelled using 4',6-diamidino-2-phenylindole (DAPI) (Molecular Probes, USA). After staining, cell monolayers were mounted using Vectashield mounting media, covered with a glass cover slip and sealed with clear varnish. Mounted samples were stored at $4{ }^{\circ} \mathrm{C}$ in the dark prior to imaging.

\subsubsection{Confocal laser scanning microscopy (CLSM)}

Labelled cells were imaged using confocal laser scanning microscopy (CLSM) using a LSM Pascal exciter (Zeiss, Germany) mounted on a Zeiss Axioimager M1 microscope (Zeiss, Germany) fitted with a $488 \mathrm{~nm}$ Argon laser, A $405 \mathrm{~nm}$ diode laser and a $543 \mathrm{~nm}$ Helium-Neon laser. Typically, as most samples were either dual or triple labelled, a multi-track setup was used and an image stack was then captured at the required resolution and z-step height. Once the Z-stack had been captured, this was processed into a 2D image using the LSM Image Examiner software (Zeiss, Germany).

\subsubsection{Scanning Electron Microscopy (SEM)}

Samples were fixed and prepared for Scanning Electron Microscopy (SEM) 
using the following protocol. After gentle washing in PBS, primary fixation was performed using $2.5 \%$ glutaraldehyde in phosphate buffered saline (PBS) at $\mathrm{pH} 7$ for $20 \mathrm{~min}$ at room temperature. After washing several times with PBS, secondary fixation was performed in $1 \%$ osmium tetroxide solution for $1 \mathrm{~h}$. The samples were again washed several times in PBS before being dehydrated using a series of graded alcohol washes. After ethanol dehydration, final chemical dehydration was carried out using hexamethyldisilazane (HMDS) before being air dried overnight.

Once dehydrated, the samples for SEM were coated in a conductive coating of gold in a K500X sputter coater (Emitech, USA) and analysed in a Quanta 200 3D scanning electron microscope (FEI, USA).

\subsubsection{Image analysis}

Fluorescent micrographs were analysed using Image $\mathbf{J}$ [ 15]. Colour or greyscale images were converted to an 8-bit greyscale type, before converting to a binary image by applying upper and lower thresholds. The threshold levels were manually adjusted to obtain the best representation of the cells or cell nuclei. Once the binary image was obtained, image analysis was performed using the particle analyser in Image $\mathbf{J}$.

For cell counting, the particle size range considered was adjusted to ensure that image artefacts that were smaller than the cell nuclei were not counted. In order to confirm the accuracy of this methodology, the nuclei on at least two images per sample were counted manually and compared with the results obtained by image analysis. Particle size range was adjusted so that these counts were within $5 \%$ of each other for all the images considered. From the cell numbers, the cell density was then determined from the full frame areas, based on the microscope objective used. Direct cell counting, based on microscopy and image analysis, was chosen as the most appropriate method for quantifying adhesion and proliferation on the various substrates, as it was possible to count cell numbers specifically for each different surface type, when a range of different surfaces were present on some samples. As the purpose was to determine the cell response to the different surface features, it was important to be able to consider these surfaces individually, which would not have been possible using biochemical assays.

To determine cell alignment and aspect ratio, fluorescent images were processed using ImageJ using a similar methodology to that employed by 
O'Cearbhaill et al. [16]. Within the particle analyser, an ellipse was fitted to each cell. From the fitted ellipses, the lengths of the major and minor axes were measured, as well as the angle the major axis made with the long axis of the image frame. From the axis lengths, the aspect ratio, sometimes known as the cell elongation index $[4,17]$ was calculated by dividing the major axis length by the minor axis length. An aspect ratio index of 1 denotes a cell that is as wide as it is long, while higher numbers indicate more elongated cells. Aspect ratios were measured on all cells from at least eight images per sample, and the mean aspect ratio calculated for each set of experimental conditions. $t$-tests, assuming equal variances were used to assess the statistical significance of any differences observed.

In order to determine the alignment of cells, histograms of the major axis angle were plotted for each sample using a method similar to Punchard et al. [18] and Charest et al. [19]. If the cells were not preferentially aligned in any direction, then the histogram would show a uniform distribution. If, however, there was preferential alignment, then a larger proportion of cells would be seen with their major axes in this range.

\section{Results}

\subsection{Micro-features created by hot embossing}

Scanning Electron and optical micrographs of the micro-features produced by hot embossing are shown in Fig. 1. The features are accurately and repeatably replicated across the $10 \mathrm{~mm}$ square array. The step heights of the microfeatures were measured by stylus profilometry, and a sample scan of a test region can be seen alongside the micrographs in Fig. 1 .

\section{Fig. 1}

SEM images of hot embossed micro-features in TCPS showing a $3.2 \mu \mathrm{m}$ ridges and $\mathbf{b}$ $3.2 \mu \mathrm{m}$ pillars. $\mathbf{c}$ shows a stylus profilometer scan indicating the $1 \mu \mathrm{m}$ step height of the features. Image $\mathbf{d}$ is an optical micrograph showing the short ridge array adjacent to an unfeatured region 
(a)
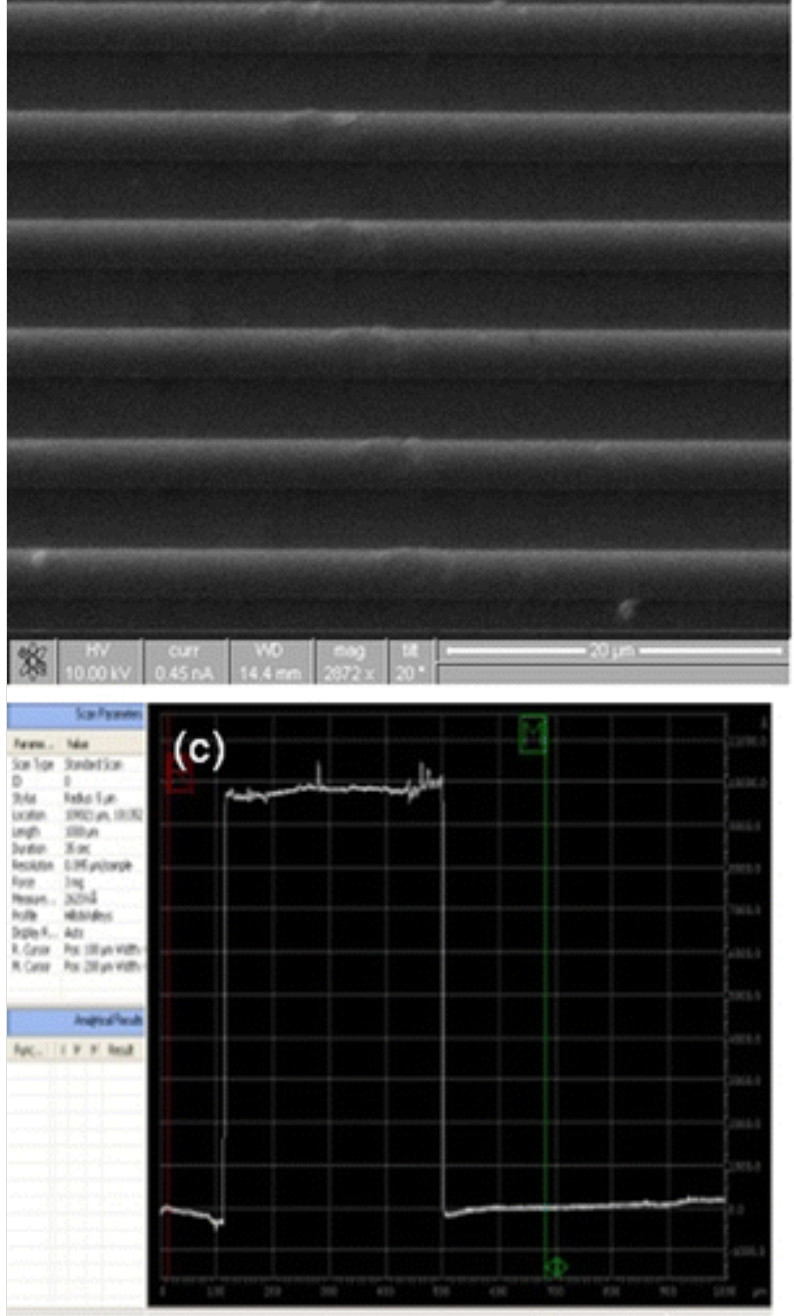

\section{(b)}

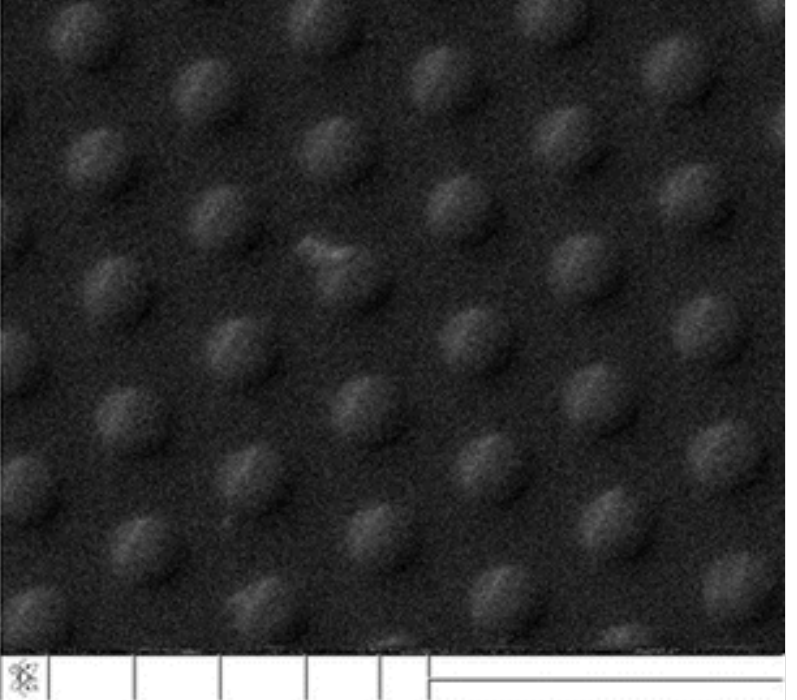

\section{(d)}

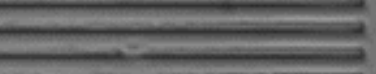

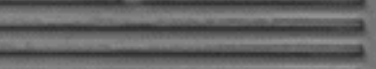

$\bar{\square}$

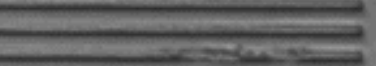

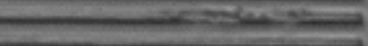

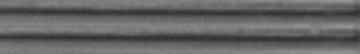

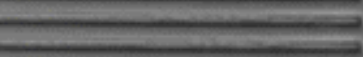

$\longrightarrow$

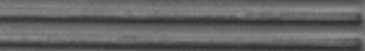

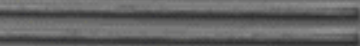

$\longrightarrow$

\subsection{Surface characterisation}

\subsubsection{Static water contact angle}

After embossing, the contact angle of the PS substrates did not significantly change, being $88.5^{\circ}$ before embossing and $87.8^{\circ}$ afterwards. However, the contact angle of the TCPS substrates increased significantly from $68.4^{\circ}$ before embossing to $88.4^{\circ}$ afterwards, and was closer to that of pristine PS than to the pristine TCPS surface. The static water contact angles are shown in Fig. 2 .

\section{Fig. 2}

Static water contact angle of PS and TCPS surfaces before and after hot embossing. ** indicates statistical significance at $P>0.01$ 


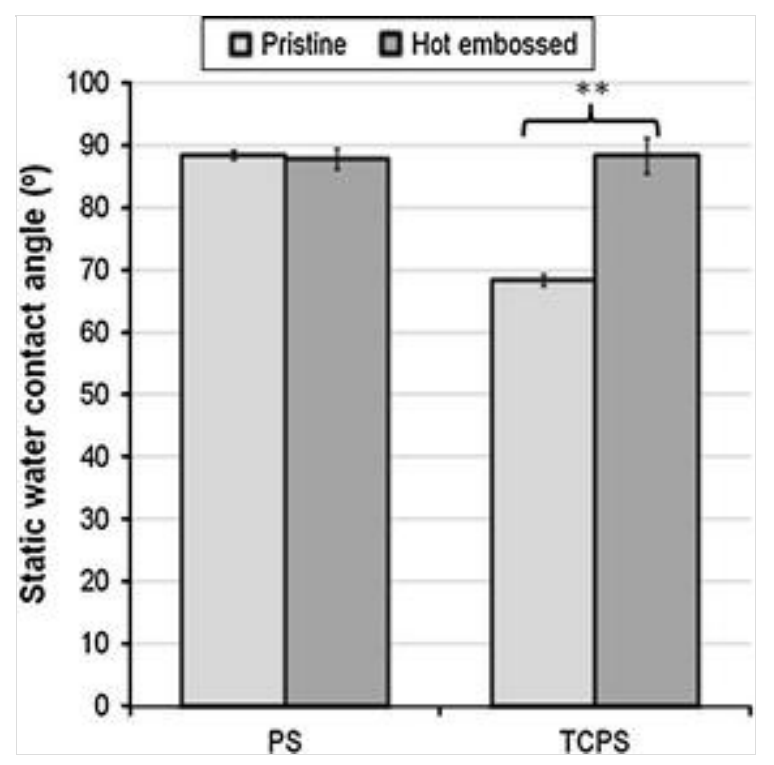

\subsubsection{Atomic force microscopy (AFM)}

AFM analysis shows that the surface of both the PS and TCPS substrates is significantly less rough after hot embossing. Images and Ra values are shown in Fig. 3 and the Ra values are shown in Table 2. Polished silicon is very smooth, with a typical Ra value of lower than $1 \mathrm{~nm}$, so it is not surprising that the hot embossing process creates a very smooth polymer surface.

\section{Fig. 3}

3-D rendering of $10 \mu \mathrm{m} \times 10 \mu \mathrm{m}$ AFM scans and arithmetic mean surface roughness on a pristine PS, $\mathbf{b}$ pristine TCPS, $\mathbf{c}$ embossed PS and $\mathbf{d}$ embossed TCPS, showing the significant reduction in surface roughness after hot embossing. Note that the z-scale for the embossed samples is $\pm 10 \mathrm{~nm}$ while that for the pristine surfaces is $\pm 30 \mathrm{~nm}$ 

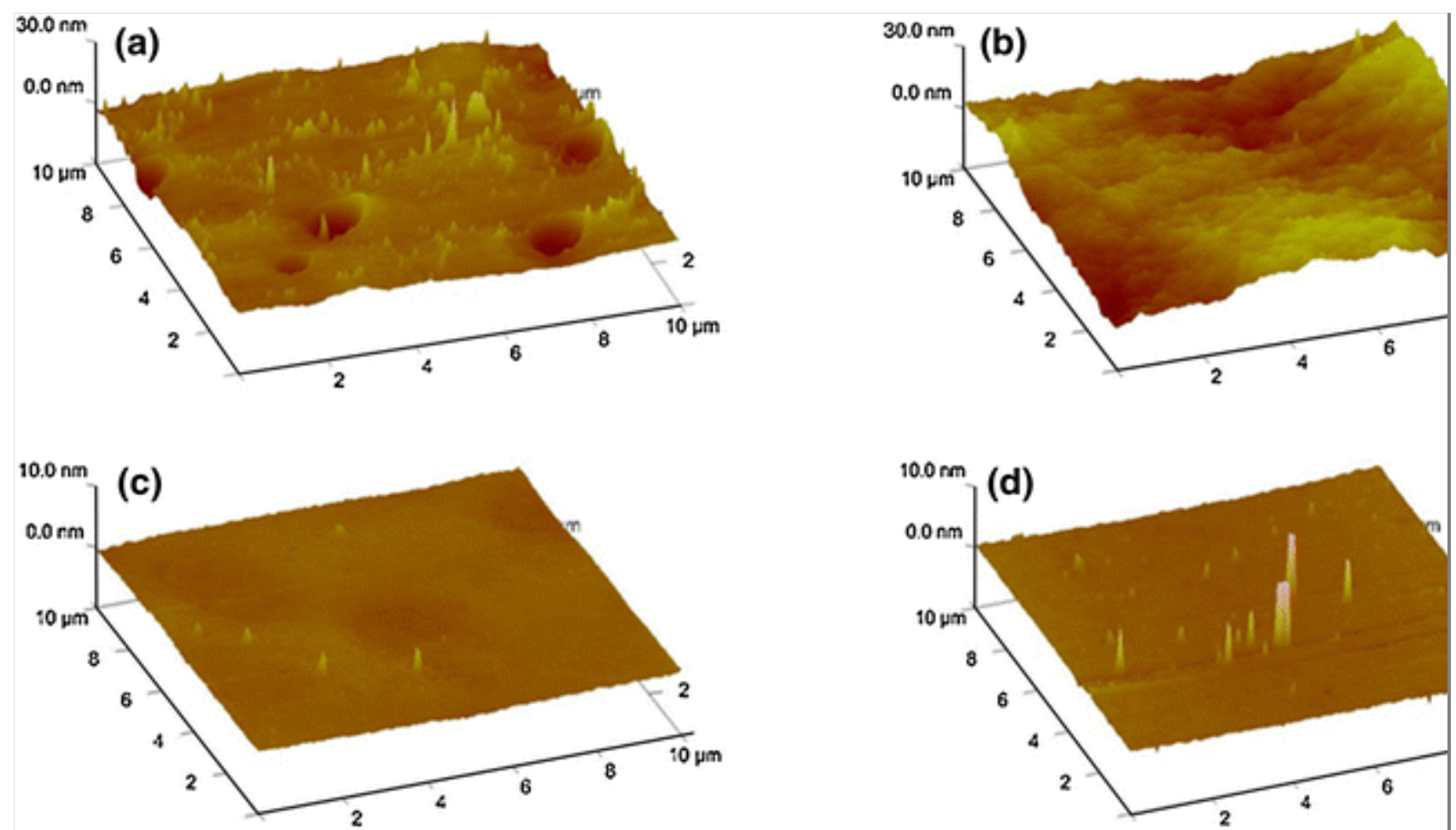

\begin{tabular}{c|c|c|c|}
\hline Image & Sample & $\mathrm{Ra}(\mathrm{nm})$ & Std error $(\mathrm{nm})$ \\
\hline (a) & Pristine PS & 1.64 & 0.17 \\
(b) & Pristine TCPS & 2.42 & 0.64 \\
(c) & Embossed PS & 0.25 & 0.04 \\
(d) & Embossed TCPS & 0.29 & 0.04 \\
\hline
\end{tabular}

\subsubsection{X-Ray photoelectron spectroscopy (XPS)}

Chemical changes to the TCPS surface were evaluated using XPS. The spectra in Fig. 4 indicate that there is a significant reduction in the atomic \% oxygen at the surface of the TCPS substrate after hot embossing. The quantification of the area under the oxygen peaks is shown in Fig. 4. The value of $9.49 \%$ for TCPS is typical of the atomic \% oxygen found after tissue culture treatment.

\section{Fig. 4}

XPS spectra for pristine TCPS showing a wide energy survey scan, $\mathbf{b}$ high resolution carbon peak, $\mathbf{c}$ high resolution oxygen peak and for hot embossed TCPS showing $\mathbf{d}$ wide energy survey scan, $\mathbf{e}$ high resolution carbon peak, $\mathbf{f}$ high resolution oxygen peak. Quantification data are shown for pristine and hot embossed PS and TCPS substrates showing a reduction in atomic oxygen after hot embossing for TCPS. The Pristine TCPS surface is statistically significantly different from all of the other surfaces at 

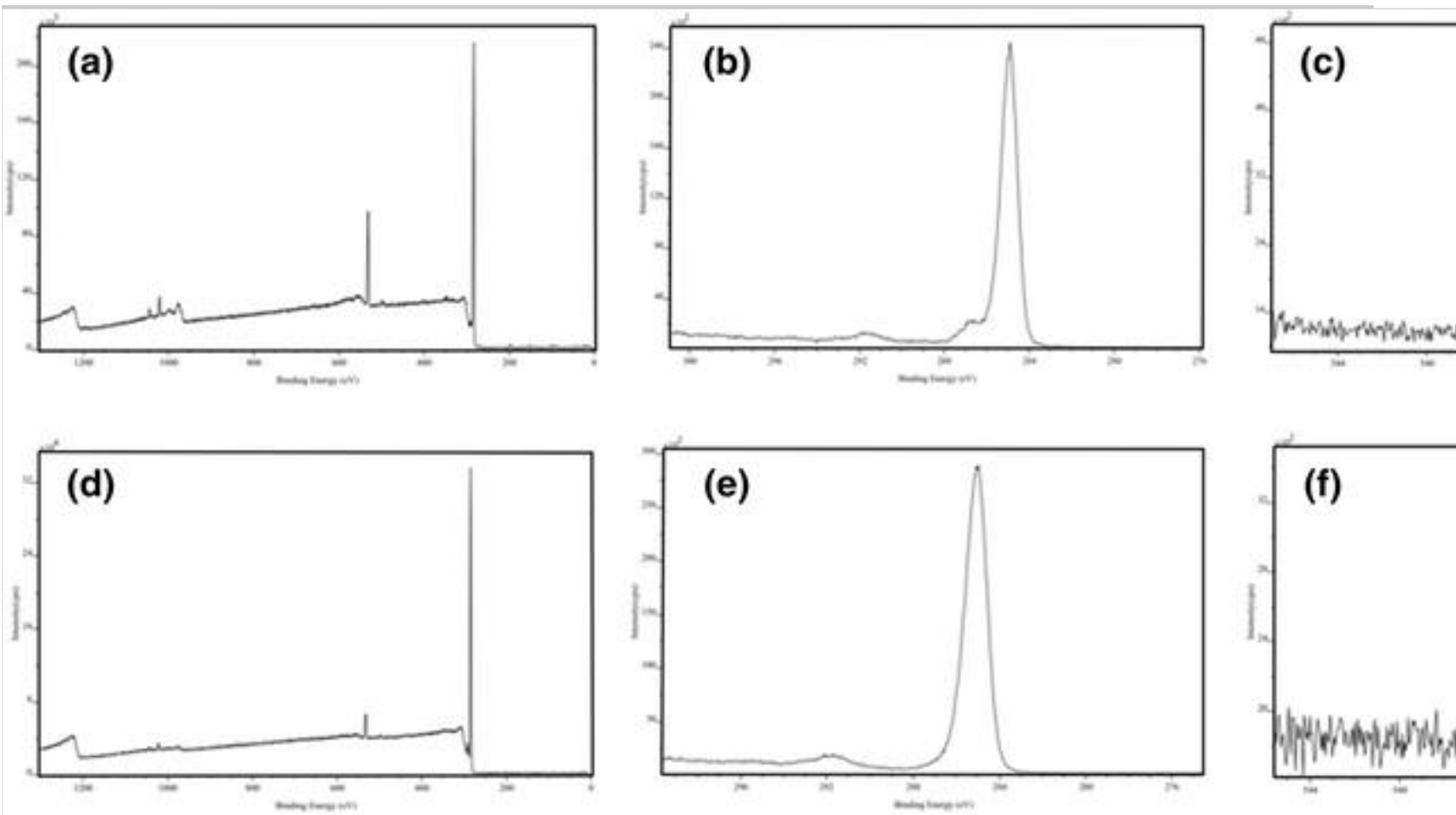

(f)
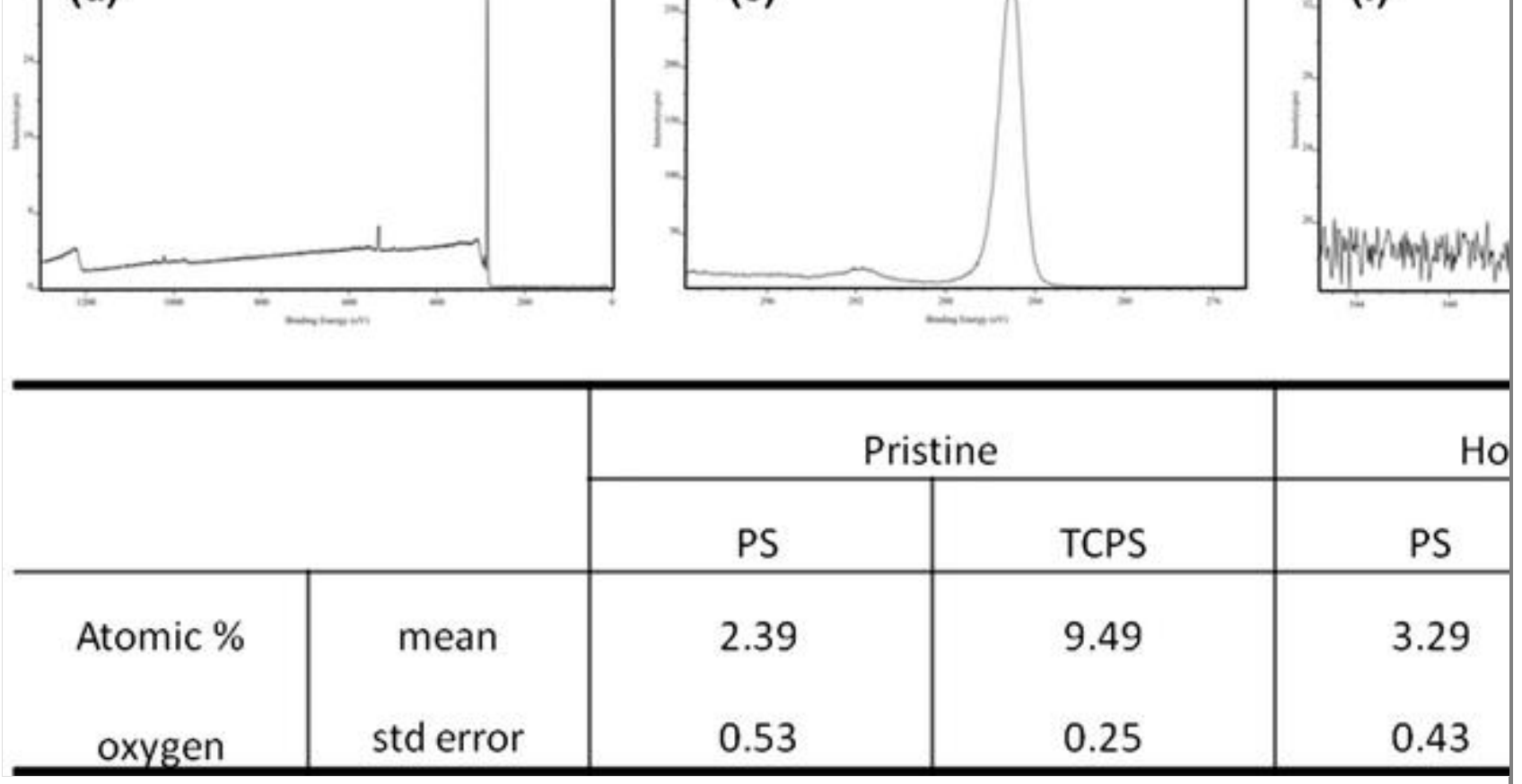

\subsection{Cell culture}

\subsubsection{Quantification of cell numbers}

After 48 and $72 \mathrm{~h}$ in culture, cell numbers were evaluated using fluorescent microscopy and image analysis, with results after $72 \mathrm{~h}$ shown in Fig. 5. After $48 \mathrm{~h}$, cell monolayers were not yet confluent on any of the substrates, while after $72 \mathrm{~h}$ the cells were confluent on the $3.2 \mu \mathrm{m}$ pillars and ridges as well as the pristine TCPS. When confluent, the cell density was lower on the $3.2 \mu \mathrm{m}$ ridges than on the $3.2 \mu \mathrm{m}$ pillars or the pristine TCPS.

\section{Fig. 5}

a cell numbers after $72 \mathrm{~h}$ in culture, showing almost an order of magnitude difference in cell number between pristine TCPS and planar embossed TCPS. b BAECs cultured on $3.2 \mu \mathrm{m}$ pillars showing preferential adhesion and proliferation on the micro-featured areas, and very little adhesion to the planar unfeatured areas. c shows the aspect ratio 
of BAECs cultured on different substrates, preferential alignment histograms after $72 \mathrm{~h}$ in culture for $\mathbf{d}$ non-aligned BAECs on pristine TCPS, e non-aligned BAECs cultured on $3.2 \mu \mathrm{m}$ pillars and $\mathbf{f}$ aligned BAECS cultured on $3.2 \mu \mathrm{m}$ ridges. CLSM images of BAECs showing actin (green) and nuclei (blue) cultured on g pristine TCPS, h $3.2 \mu \mathrm{m}$ pillars and $\mathbf{i} 3.2 \mu \mathrm{m}$ ridges after $72 \mathrm{~h}$ in culture
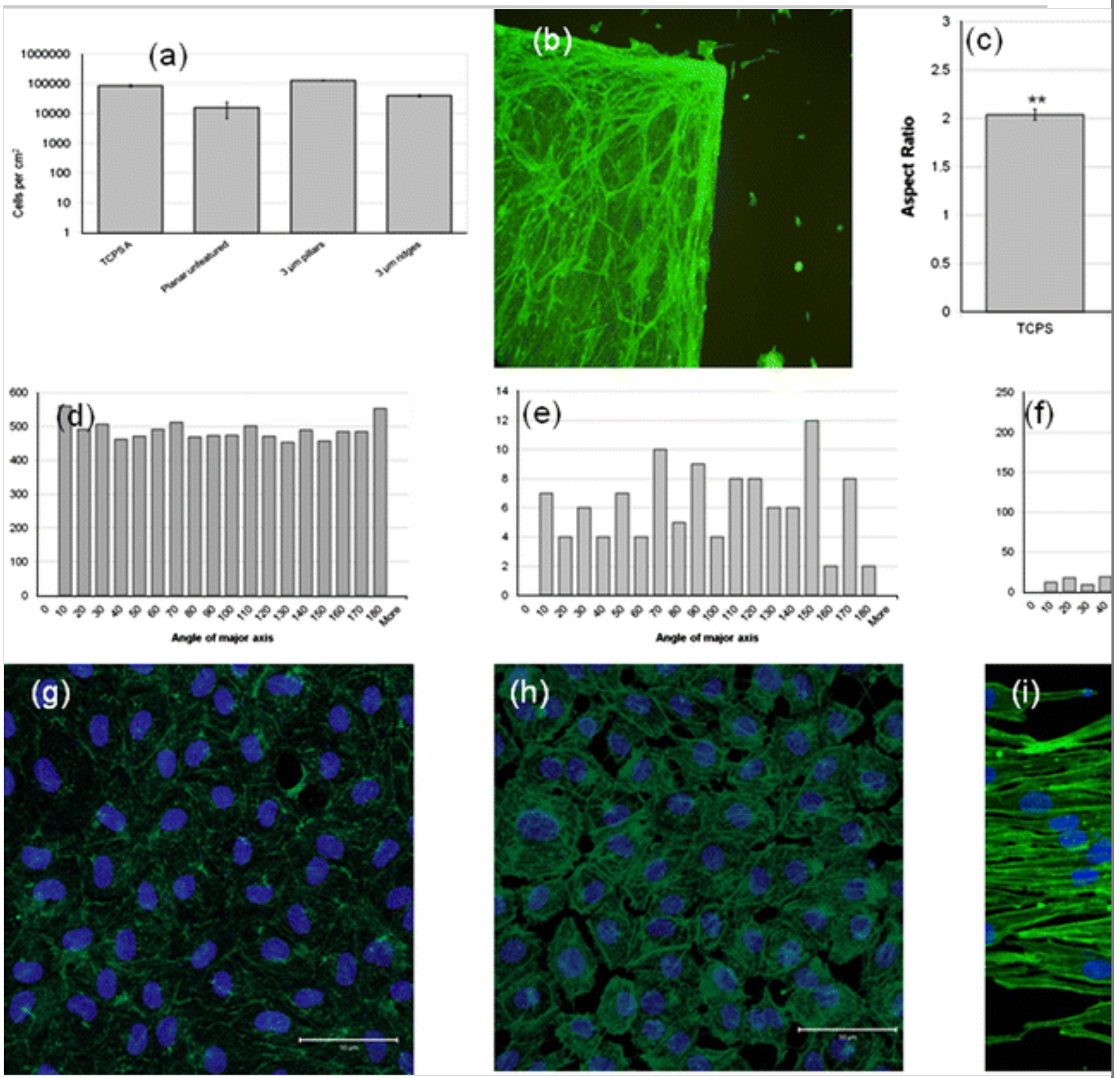

The planar embossed TCPS substrates showed the lowest cell numbers, as shown in Fig. 5 a. It can be clearly seen in the micrographs in Fig. 5 b, that where micro-features and planar embossed surfaces exist side-by-side, that BAECs preferentially adhere and proliferate on the micro-features.

\subsubsection{Cell aspect ratio and alignment}

As is expected, cells align and elongate in the direction of the micro-scale 
ridge features. The aspect ratios of BAECs after $48 \mathrm{~h}$ in culture are shown in Fig. $5 \mathrm{c}$, and the histograms showing the preferential alignment of BAECs on the ridge features are shown in Fig. 5d, e. No significant difference is observed in the aspect ratio or alignment of cells cultured on any of the pillar features or the pristine TCPS. Representative CLSM images of BAECs on microfeatured surfaces are shown in Fig. $5 \mathrm{f}$, g.

\subsubsection{Directional tubule formation}

After a further 7-10 days in culture (10-13 days in total), BAECs appear to have formed cord or tube structures on the substrates with the $200 \mu \mathrm{m}$ long ridges. SEM and CLSM images of these tubules are shown in Fig. 6. These cords or tubes are formed in a direction that is perpendicular to the individual ridge features, i.e. they are formed parallel to the long axis of the patterned strip. The diameter of these structures varies, suggesting that they may initially form as cords or capillaries and subsequently grow in diameter.

\section{Fig. 6}

Tubules formed on short ridge arrays after 10 days in culture: a shows a scanning electron micrograph of tubules, $\mathbf{b}$ is a low magnification CLSM image of a number of tubules formed on several parallel short ridge arrays. Image $\mathbf{c}$ is a projection of a CLSM image stack of a single tubule on a short ridge, similar to the circled region in (b). Image (d) is a projected image from the CLSM stack of the cross section A-A', showing a tubular structure 

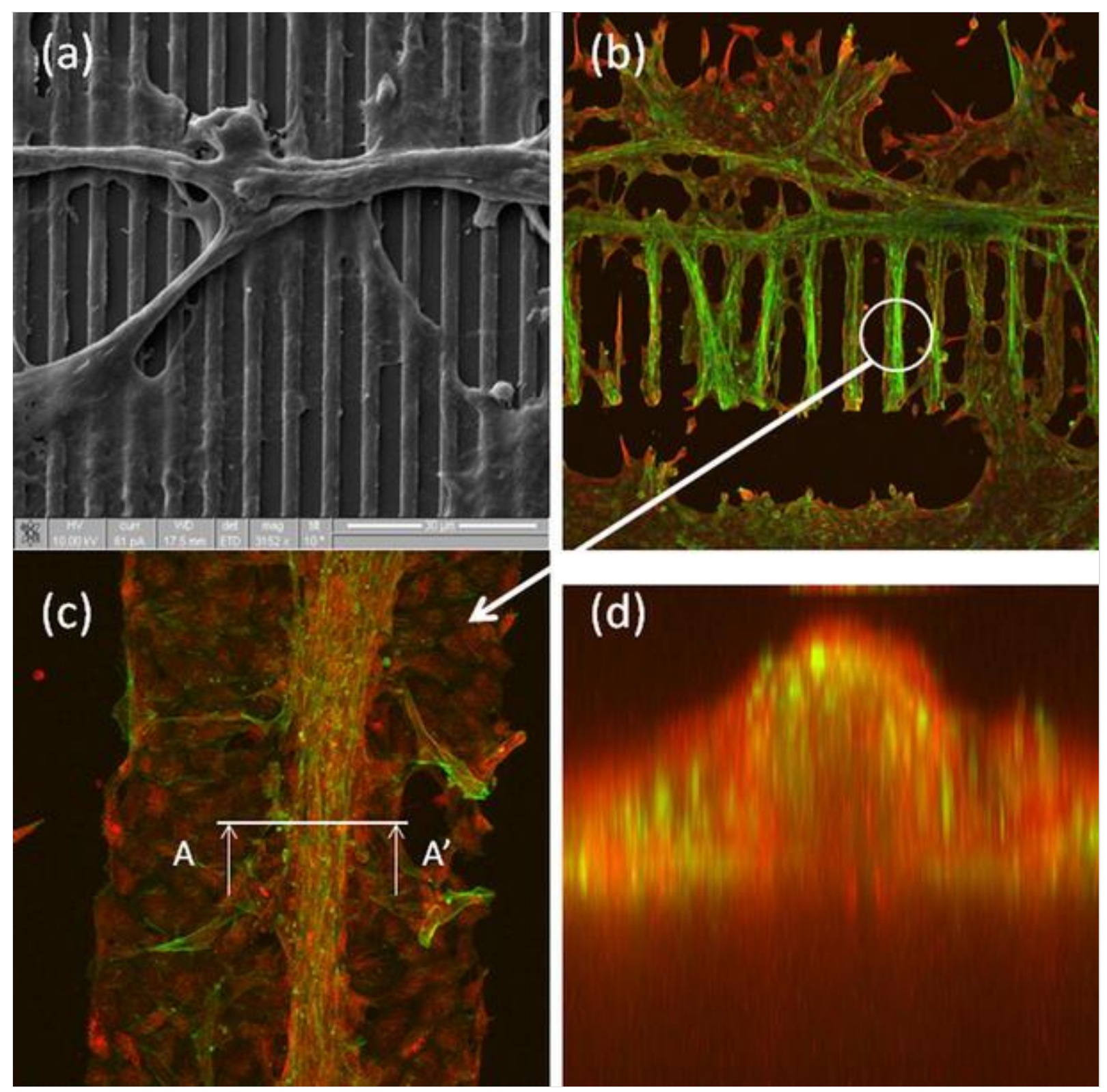

SEM and CLSM images of these tubules are shown in Fig. 6.

\section{Discussion}

\subsection{The effect of hot embossing on tissue culture treated} polystyrene

Hot embossing has been used here to produce repeatable micro-scale features in both PS and TCPS substrates. Hot embossing of PS shows a reduction in surface roughness after hot embossing using a silicon stamp, as measured by AFM, but no significant change in water contact angle or in the surface chemistry of PS, as measured by XPS. In contrast, when tissue culture treated polystyrene (TCPS) is considered, the surface analysis undertaken here indicates that the hot embossing process changes the chemistry of the surface significantly as well as changing its topography. The contact angle of the 
TCPS increases significantly after embossing. This research has shown that embossing TCPS substrates at $110{ }^{\circ} \mathrm{C}$ and $10 \mathrm{kN}$ produces a surface that is significantly more hydrophobic than pristine TCPS.

Polished silicon typically has a surface roughness of $1 \mathrm{~nm}$ or less [20], measured by AFM, so it is to be expected that embossing PS or TCPS with such a surface will result in a reduction in surface roughness.

The effects of hot embossing on TCPS are supported by the XPS analysis which indicates that atomic oxygen concentration at the surface for the pristine TCPS substrate shows 9.5 at.\% oxygen at the surface, while the pristine PS substrate contains approximately 2.4 at.\% oxygen at the surface. These values are comparable to those found in the literature for polystyrene and plasma treated polystyrene [11]. The surface treatment of polymers using plasmas has been shown to be degraded by ageing, where the mobility of the polymer chains result in a gradual movement of polar functional groups into the bulk of the polymer [21]. This mobility will be greatly increased by heating the polymer to its glass transition temperature during the hot embossing process, consistent with the results observed here. The combined effect of a reduction in surface roughness and a reduction in the oxygen containing polar functional groups at the polymer surface is consistent with the increase in water contact angle observed in this research.

The effect of hot embossing on the TCPS surface chemistry has not been reported previously, and has important implications for the subsequent adhesion of cells to these surfaces in the context of the use of hot embossing processes for the production of micro-scale features in treated polymer surfaces for cell culture, as the maximum cell adhesion of a range of cell types cells has been reported at water contact angles of around $55^{\circ}[13,22]$, with poorer adhesion at both higher and lower contact angles. It is therefore expected that cells cultured on TCPS and hot embossed TCPS will behave differently. Considering the low levels of cell adhesion of to pristine PS, adhesion of cells to embossed, planar TCPS surfaces is likely to be lower than to non-embossed TCPS surfaces.

\subsection{BAEC response to hot embossed TCPS surfaces}

\subsubsection{Cell numbers, aspect ratio and alignment}

BAECs adhere significantly less well to planar, non-featured TCPS after hot 
embossing. It is clear that the changes in the surface chemistry, roughness and subsequent wettability of the TCPS surface that result from the hot embossing have a significant effect on the biological response to these substrates. The surface characterisation data presented above indicate that the commercial surface treatment of the TCPS, which increases wettability by the incorporation of oxygen and roughening of the surface $[11-13,22]$ is degraded by hot embossing. It is thus perhaps not surprising that cell adhesion and proliferation on these degraded surfaces is poorer than for the pristine TCPS surface.

When the different embossed features are considered.

While the wettability of the surface is degraded by the embossing process, as has been discussed, the embossed features appear to provide additional areas for cell attachment on the embossed substrates, and the resulting cell numbers in micro-featured areas are therefore much higher than in non-featured areas. When ridge and pillar features are compared, the shape of the cells and their alignment is significantly different. BAECs cultured on ridge structures preferentially align in the direction of the ridges. Cell alignment has been noted for endothelial cells on micro-patterned topographies $[6,17,23]$ and micro-patterned chemical patterns $[\mathbf{1 0}, 24,25]$ in the literature. Aligned cells on ridge features are also significantly elongated when compared with those cultured on pillar structures or on planar TCPS control surfaces $[7,19,26$, 27]. Cells are typically observed to attach primarily to the tops and edges of the micro-features structures, rather than in the grooves or between pillars. This means that the area available for cellular attachment is higher in the groove direction than in the orthogonal direction, and cells will therefore have a higher probability of aligning in the ridge direction.

The combination of tissue culture treatment and hot embossing is able to provide a mechanism to control both the topography and the surface chemistry of polystyrene cell culture substrates. Spatial control of these surface properties can enable the precise patterning of both adhesive and non-adhesive regions on a single substrate using techniques that are both simple and amenable to industrial application.

\subsubsection{Spatial control of tubule formation}

After a number of days in culture, specifically on short ridge arrays, BAECs form cord or tube structures, part of the process of angiogenesis. While this 
phenomenon has been clearly and repeatably observed after culture on these specific micro-featured surfaces, significant further work is required to understand both the mechanisms involved and the precise nature of these structures.

While angiogenesis has been reported in response to patterns of extracellular matrix [28], polymer fibres [29, 30], biochemical stimuli [31-34], wall shear stress $[33,35]$, within deep grooves $[36,37]$ and in co-culture [38-40] the spatial control of tubule formation in response to micro-scale surface features, without biochemical stimulus has not been reported in the literature. This observation has been shown to be repeatable with different cell populations. However, the origin of the mechano-biological stimuli and the biological signaling processes involved are not yet clear [41].

Preferential adhesion to the micro-featured regions is clearly a key step in the processes which enable the spatial control of tubule formation. As has been indicated, preferential adhesion to the micro-featured regions was observed for hot embossed TCPS material, without the use of any biochemical or biological factors.

\section{Conclusions}

In this paper, we have reported a method that provides for patterning of cell adhesive regions on TCPS, without using biochemical factors. The method produces a surface that has regions of precisely defined micro-structural features with adjoining planar unfeatured regions. The provision of this substrate topography, combined with attendant control of surface chemistry, results in preferential cell adhesion to the micro-featured areas. Alignment is observed, as expected, when endothelial cells are cultured on ridge and groove features, but not on pillar features.

Hot embossing of previously treated Tissue Culture Polystyrene (TCPS) has been shown in this research to have a pronounced effect on both the topography and surface chemistry of the cell culture substrate. This effect that hot embossing has on TCPS surface chemistry has not been reported previously, but clearly has important implications for the subsequent adhesion of cells to these surfaces. An interesting observation that requires further analysis is the formation of cord or tube structures in clearly controlled locations and directions by endothelial cells when cultured on specific patterned substrates. 
By using relatively simple fabrication processes, it is therefore possible to create an inexpensive polymer substrate that contains both adhesive and non-adhesive regions. The ability to pattern cell adhesion has been shown previously by adding grafted polymers or protein coatings, but not using a simple bulk processing method as demonstrated here. This methodology may have applications in the design of scaffolds for tissue engineering, and in the development of assays for evaluating angiogenesis, with the potential for use in automated assays for high throughput screening.

\section{References}

1. Shamloo A, Xu H, Heilshorn S. Mechanisms of vascular endothelial growth factor-induced pathfinding by endothelial sprouts in biomaterials. Tissue Eng Part A. 2012;18:320-30.

2. Gao D, Kumar G, Co C, Ho CC. Formation of capillary tube-like structures on micropatterned biomaterials. Adv Exp Med Biol. 2008;614:199-205.

3. Gafni Y, Zilberman Y, Ophir Z, Abramovitch R, Jaffe M, Gazit Z, Domb A, Gazit D. Design of a filamentous polymeric scaffold for in vivo guided angiogenesis. Tissue Eng. 2006;12:3021-34.

4. Uttayarat P, Lelkes PI, Composto RJ. Effect of nano-to micro-scale surface topography on the orientation of endothelial cellsProc. MRS Symposium 845, 157 - 162, . 2005.

5. Liliensiek SJ, Wood JA, Yong J, Auerbach R, Nealey PF, Murphy CJ. Modulation of human vascular endothelial cell behaviors by nanotopographic cues. Biomaterials. 2010;31:5418-26.

6. Uttayarat P, Toworfe GK, Dietrich F, Lelkes PI, Composto RJ. Topographic guidance of endothelial cells on silicone surfaces with microto nanogrooves: orientation of actin filaments and focal adhesions. $\mathbf{J}$ Biomed Mater Res Part A. 2005;75A:668-80.

7. Biela SA, Su Y, Spatz JP, Kemkemer R. Different sensitivity of human endothelial cells, smooth muscle cells and fibroblasts to topography in the nano-micro range. Acta Biomater. 2009;5:2460-6. 
8. Kidoaki S, Matsuda T. Shape-engineered vascular endothelial cells: nitric oxide production, cell elasticity, and actin cytoskeletal features. J Biomed Mater Res A. 2007;81:728-35.

9. Kato S, Ando J, Matsuda T. MRNA expression on shape-engineered endothelial cells: adhesion molecules ICAM-1 and VCAM-1. J Biomed Mater Res. 2001;54:366-72.

10. Vartanian KB, Kirkpatrick SJ, Hanson SR, Hinds MT. Endothelial cell cytoskeletal alignment independent of fluid shear stress on micropatterned surfaces. Biochem Biophys Res Commun. 2008;371:787-92.

11. D'Sa RA, Burke GA, Meenan BJ. Protein adhesion and cell response on atmospheric pressure dielectric barrier discharge-modified polymer surfaces. Acta Biomater. 2010;6:2609-20.

12. Liu C, Cui N, Brown NMD, Meenan BJ. Effects of DBD plasma operating parameters on the polymer surface modification. Surf Coat Technol. 2004;185:311-20.

13. Lee JH, Khang G, Lee JW, Lee HB. Interaction of different types of cells on polymer surfaces with wettability gradient. J Colloid Interface Sci. 1998;205:323-30.

14. Chan C-, Ko T-, Hiraoka H. Polymer surface modification by plasmas and photons. Surf Sci Rep. 1996;24:1-54.

15. Rasband WS. ImageJ. 2009.

16. O'Cearbhaill ED, Punchard MA, Murphy M, Barry FP, McHugh PE, Barron V. Response of mesenchymal stem cells to the biomechanical environment of the endothelium on a flexible tubular silicone substrate. Biomaterials. 2008;29:1610-9.

17. Potter CMF, Schobesberger S, Lundberg MH, Weinberg PD, Mitchell JA, Gorelik J. Shape and compliance of endothelial cells after shear stress in vitro or from different aortic regions: scanning ion conductance microscopy study. PLoS One. 2012;7:e31228.

18. Punchard M, O'Cearbhaill E, Mackle J, McHugh P, Smith T, 
Stenson-Cox C, Barron V. Evaluation of human endothelial cells post stent deployment in a cardiovascular simulator in vitro. Ann Biomed Eng. 2009;37:1322-30.

19. Charest JL, Bryant LE, Garcia AJ, King WP. Hot embossing for micropatterned cell substrates. Biomaterials. 2004;25:4767-75.

20. Teichert C, Mackay J, Savage D, Lagally M, Brohl M, Wagner P. Comparison of surface-roughness of polished silicon-wafers measured by light-scattering topography, soft-X-ray scattering, and atomic-force microscopy. Appl Phys Lett. 1995;66:2346-8.

21. Banik I, Kim KS, Yun YI, Kim DH, Ryu CM, Park CS, Sur GS, Park CE. A closer look into the behavior of oxygen plasma-treated high-density polyethylene. Polymer. 2003;44:1163-70.

22. Lee JH, Lee SJ, Khang G, Lee HB. The effect of fluid shear stress on endothelial cell adhesiveness to polymer surfaces with wettability gradient. J Colloid Interface Sci. 2000;230:84-90.

23. Uttayarat P, Chen M, Li M, Allen FD, Composto RJ, Lelkes PI. Microtopography and flow modulate the direction of endothelial cell migration. Am J Physiol Heart Circ Physiol. 2008;294:H1027-35.

24. Chen CS, Mrksich M, Huang S, Whitesides GM, Ingber DE. Micropatterned surfaces for control of cell shape, position, and function. Biotechnol Prog. 1998;14:356-63.

25. Gorelick S, Rahkila P, Sagari A, Sajavaara T, Cheng S, Karlsson LB, van Kan JA, Whitlow HJ. Growth of osteoblasts on lithographically modified surfaces. Nucl Instrum Methods Phys Res Sect B.

2007;260:130-5.

26. Curtis A, Wilkinson C. Topographical control of cells. Biomaterials. 1997;18:1573-83.

27. Hsu S, Thakar R, Liepmann D, Li S. Effects of shear stress on endothelial cell haptotaxis on micropatterned surfaces. Biochem Biophys Res Commun. 2005;337:401-9. 
28. Wong M, Gotlieb A. Endothelial cell monolayer integrity. I. Characterization of dense peripheral band of microfilaments. Arterioscler Thromb Vasc Biol. 1986;6:212-9.

29. Sukmana I, Vermette P. Polymer fibers as contact guidance to orient microvascularization in a $3 \mathrm{D}$ environment. J Biomed Mater Res Part A. 2010;92A:1587-97.

30. Bauer AL, Jackson TL, Jiang Y. Topography of extracellular matrix mediates vascular morphogenesis and migration speeds in angiogenesis. PLoS Comput Biol. 2009;5:e1000445.

31. Unger RE, Peters K, Huang Q, Funk A, Paul D, Kirkpatrick CJ. Vascularization and gene regulation of human endothelial cells growing on porous polyethersulfone (PES) hollow fiber membranes. Biomaterials. 2005;26:3461-9.

32. Eichmann A, Noble FL, Autiero M, Carmeliet P. Guidance of vascular and neural network formation. Curr Opin Neurobiol. 2005;15:108-15.

33. Dike L, Chen C, Mrksich M, Tien J, Whitesides G, Ingber D. Geometric control of switching between growth, apoptosis, and differentiation during angiogenesis using micropatterned substrates. In Vitro Cell Dev Biol Anim. 1999;35:441-8.

34. Sukmana I, Vermette P. The effects of co-culture with fibroblasts and angiogenic growth factors on microvascular maturation and multi-cellular lumen formation in HUVEC-oriented polymer fibre constructs. Biomaterials. 2010;31:5091-9.

35. Song JW, Munn LL. Fluid forces control endothelial sprouting. Proc Natl Acad Sci USA. 2011;108:15342-7.

36. Kaunas R, Kang H, Bayless K. Synergistic regulation of angiogenic sprouting by biochemical factors and wall shear stress. Cell Mol Bioeng. 2011;4:547-59.

37. Wang H, Chen S, Ratner BD, Sage EH, Jiang S. Capillary differentiation of endothelial cells on microgrooved surfaces. J Phys Chem C. $2007 ; 111: 14602-6$. 
38. Hofmann A, Ritz U, Verrier S, Eglin D, Alini M, Fuchs S, Kirkpatrick CJ, Rommens PM. The effect of human osteoblasts on proliferation and neo-vessel formation of human umbilical vein endothelial cells in a long-term 3D co-culture on polyurethane scaffolds. Biomaterials. 2008;29:4217-26.

39. Liu Y, Markov DA, Wikswo JP, McCawley LJ. Microfabricated scaffold-guided endothelial morphogenesis in three-dimensional culture. Biomed Microdevices. 2011;13:837-46.

40. Unger RE, Sartoris A, Peters K, Motta A, Migliaresi C, Kunkel M, Bulnheim U, Rychly J, James Kirkpatrick C. Tissue-like self-assembly in cocultures of endothelial cells and osteoblasts and the formation of microcapillary-like structures on three-dimensional porous biomaterials. Biomaterials. 2007;28:3965-76.

41. Fuchs S, Hofmann A, Kirkpatrick CJ. Microvessel-like structures from outgrowth endothelial cells from human peripheral blood in 2-dimensional and 3-dimensional co-cultures with osteoblastic lineage cells. Tissue Eng. 2007;13:2577-88. 